\title{
PENGARUH MOTIVASI, STRES, DAN LINGKUNGAN BELAJAR ISLAMI TERHADAP PRESTASI BELAJAR DENGAN LINGKUNGAN BELAJAR ISLAMI SEBAGAI VARIABEL INTERVENING
}

\author{
Ismartaya \\ Program Studi Manajemen Fakultas Ekonomi, Universitas Djuanda Bogor \\ Email : ismartaya@unida.ac.id
}

\begin{abstract}
ABSTRAK
Penelitian ini bertujuan untuk mengetahui pengaruh motivasi dan stres terhadap prestasi belajar dengan kovariabel lingkungan belajar Islami pada Prodi Manajemen Universitas Djuanda Bogor Studi Kasus pada Mahasiswa Prodi Manajemen Fakultas Ekonomi Universitas Djuanda Bogor. Penelitian ini menggunakan pola dasar The Posttest Only Control Group dengan kovariabel lingkungan belajar Islami. Teknik pengumpulan data menggunakan wawancara dan kuesioner, sedangkan teknik pengambilan sampel menggunakan non probability sampling dengan jumlah sampel 296 mahasiswa. Hasil penelitian menunjukkan bahwa motivasi dan stres berpengaruh positif dan signifikan terhadap prestasi belajar melalui lingkungan belajar Islami. Hal ini terlihat dari hasil analisis regresi linier sederhana, regresi linier berganda, uji t, uji koefisien determinasi, uji sobel dan analisis jalur. Lingkungan belajar Islami sebagai variabel moderator memediasi antara motivasi terhadap prestasi belajar yang bersifat mediasi parsial maupun lingkungan belajar Islami sebagai variabel moderator yang memediasi antara stres terhadap prestasi belajar yang keduanya merupakan mediasi penuh.
\end{abstract}

Kata Kunci : Motivasi, Stres, Lingkuangan Belajar Islami, Prestasi Belajar.

\begin{abstract}
This study aims to find out the influence of motivation and stress on learning achievements by covalent islamic learning environment at the Management Study Program of the University of Djuanda Bogor Case Study of Management Study Program Faculty of Economics, University of Djuanda Bogor. This study uses the archeany of The Posttest Only Control Group with the covalent Islamic learning environment. Data collection techniques use interviews and questionnaires, while sampling techniques using non probability sampling with a sample of 296 students. The results showed that motivation and stress have a positive and significant effect on learning achievement through islamic learning environment. This can be seen from the results of simple linear regression analysis, multiple linear regression, $t$ test, determination coefficient test, sobel test and path analysis. Islamic learning environment as a moderator variable mediates between motivation to learning achievement that is partial mediation and Islamic learning environment as moderator variables that mediate between stress to learning achievement which are both full mediation.
\end{abstract}

Keyword : Motivation, Stress, Islamic Learning Environment, Learning Achievement. 


\section{PENDAHULUAN}

Penelitian yang berjudul "Academic Performance and Perceived Stress Among University Students" tentang pengaruh stres akademik terhadap prestasi belajar. Hasil dari penelitian tersebut adalah bahwa stres akademik mempunyai hasil yang signifikan terhadap kinerja akademik, selain itu penelitian ini menampilkan hasil tingkatan stres yang terjadi pada mahasiswa sehingga jika stres akademik menempati level yang tinggi maka kinerja akademik menjadi menurun.

Penelitian tentang akademik stres tentang "Effect of Perceivedm Academic Stress on Students' Performance" yang memaparkan hubungan antara akademik stres terhadap kinerja siswa atau prestasi belajar siswa. Hasil analisis pada penelitian ini menunjukan bahwa stres akademik memiliki hubungan positif yang signifikan dengan kinerja siswa atau prestasi belajar siswa. Semakin rendah tingkat stres siswa maka kinerja akademik atau prestasi belajar siswa akan semakin meningkat. Persamaan dengan penelitian diatas yaitu terletak pada stres akademik yang dijadikan sebagai variabel independen (X1) dan kinerja akademik atau prestasi belajar sebagai variabel dependen (Y). Letak perbedaan pada penelitian ini yaitu pada emosi yang dijadikan sebagai variabel dependen dua (X2) dan terletak pada variabel intervening yaitu motivasi belajar (Z).

Persamaan dari penelitian tersebut dan penelitian yang akan dilakukan adalah bahwa stres akademik sebagai variabel independen (X) dan prestasi belajar sebagai variabel dependen (Y). Perbedaannya terletak pada varibel intervening berupa Lingkungan Islami $(\mathrm{Z})$ yang akan dilakukan untuk peneliti di Universitas Djuanda Bogor.

Mahasiswa di Indonesia setiap tahunnya mengalami peningkatan. Peningkatan jumlah mahasiswa ini, masih perlu mengalami pendampingan yang intensif guna pencapaian mahasiswa Universitas Djuanda yang mandiri, tangguh, dan berkualitas agar memiliki kemampuan memecahkan masalah baik bagi dirinya dan masyarakat. Perkembangan mahasiswa di Indonesia khususnya di Bogor terus berkembang dan terus meningkat khususnya kemampuan sumber daya manusia. Keberadaan motivasi, stres dan lingkungan belajar Islami menjadi kunci kesuksesan sebuah prestasi belajar bagi mahasiswa. Para mahasiswa membutuhkan keberadaan motivasi, stres dan lingkungan belajar Islami untuk meningkatkan kemampuan ke ilmuan akademik dan Non akademik. Pendidikan perguruan tinggi merupakan suatu sistem yang dituntut pembelajaran yang mandiri dan disiplin, kemudian dalam setiap kegiatan pembelajaran selalu didasari oleh keinginan dari individu selaras dengan visi misi perguruan tinggi.

Motivasi belajar dipengaruhi oleh dua aspek yaitu aspek intrinsik dan aspek ekstrinsik. Aspek intrinsik menggambarkan motivasi internal seseorang untuk melakukan sesuatu agar bisa mencapai tujuannya, misal seorang mahasiswa manajemen akan belajar karena senang dengan pelajaran tersebut. Aspek ekstrinsik menggambarkan motivasi seseorang untuk mendapatkan sesuatu karena dipengaruhi adanya imbalan atau hukuman, misal seorang mahasiswa akan belajar karena dia harus mendapatkan nilai yang baik.

Stres merupakan suatu keadaan yang tidak diinginkan mahasiswa. Pada kondisi stres terjadi kesenjangan antara tuntutan lingkungan belajar dengan kemampuan mahasiswa dalam mengatasi stress. Menurut Newstrom dan Davis (2007), seseorang akan terpengaruh emosi, proses, pikiran dan kondisi fisiknya akibat merespon terhadap stres. Penggolongan stres terdiri dari dua jenis, yaitu stres yang membangun (eustress). 
Eustress membuat seseorang bersemangat dan meningkatkan konsentrasi belajar, sedangkan stres yang sifatnya tidak menyenangkan, bersifat negatif (distress). Distress memberikan berbagai dampak negatif seperti menjadi mudah marah, tekanan darah tinggi, gugup, mengakibatkan sulit berkonsentrasi.

Keadaan stres yang dialami mahasiswa di dunia perkuliahan khususnya di Prodi Manajemen Universitas Djuanda Bogor sering disebut sebagai stres akademik. Stres akademik tergolong jenis stres negatif (distress). Stres akademik muncul ketika terlalu banyak tuntutan dan tugas yang harus dikerjakan oleh seorang mahasiswa. Stres juga biasa terjadi akibat tekanan untuk menunjukkan prestasi belajar dan keunggulan akademik.

Pencapaian hasil belajar mahasiswa tidak hanya dipengaruhi oleh stres saja, namun terdapat hal lain yang ikut mempengaruhi yaitu motivasi belajar dan lingkungan belajar. Keadaan stres negatif pada seseorang akan mengakibatkan mahasiswa menjadi malas dan tidak tertarik melakukan kegiatan. Akibatnya apabila seorang mahasiswa mengalami stres akan terjadi penurunan minat belajar. Minat belajar adalah suatu ketertarikan seseorang terhadap pelajaran. Minat belajar merupakan alat yang mendorong seseorang termotivasi dalam belajar. Menurut Sakamoto et all (2005) peningkatan stres pada mahasiswa akan menurunkan tingkat motivasi seseorang, sehingga peneliti tertarik untuk meneliti hubungan antara motivasi, stres terhadap prestasi belajar mahasiswa prodi manajemen semester satu, semester tiga dan semester tujuh prodi manajemen Fakultas Ekonomi Universitas Djuanda Bogor pada tahun 2020, dan Lingkungan belajar Islami sebagai variabel moderator yang memediasi antara motivasi, stres terhadap prestasi belajar yang keduanya merupakan mediasi penuh. Lingkungan belajar yang Islami merupakan lingkungan yang didalamnya terdapat kedamaian dan berlangsung kegiatan atau aktifitasaktifitas yang mencerminkan kepatuhan dan ketundukan serta penyerahan diri kepada Allah SWT. Menurut Abuddin (2013), lingkungan yang Islami adalah lingkungan atau tempat yang sangat berguna untuk menunjang suatu kegiatan, termasuk kegiatan pendidikan, karena tidak ada satu pun kegiatan yang tidak memerlukan tempat dimana kegiatan itu diadakan. Sebagai lingkungan tarbiyah Islamiyah, lingkungan mempunyai fungsi antara lain menunjang terjadinya proses kegiatan belajar mengajar secara aman, tertib, dan berkelanjutan.

\section{TINJAUAN PUSTAKA}

\section{Motivasi}

Menurut Mc. Donald dalam Hamalik, 2011 motivasi adalah perubahan energi dalam diri (pribadi) seseorang yang ditandai dengan timbulnya perasaan dan reaksi untuk mencapai tujuan.

A. M (2010) dalam kegiatan belajar motivasi dapat dikatakan sebagai keseluruhan daya penggerak di dalam diri siswa yang menimbulkan kegiatan belajar, sehingga tujuan yang dikehendaki oleh subjek belajar itu dapat tercapai.

Dalyono (2009) motivasi belajar adalah suatu daya penggerak atau dorongan yang dimiliki oleh manusia untuk melakukan suatu pekerjaan yaitu belajar.

Widoyoko (2012) motivasi adalah kondisi yang muncul dalam diri individu yang disebabkan oleh interaksi antara motif dengan kejadian-kejadian yang diamati oleh individu, sehingga mendorong mengaktifkan perilaku menjadi tindakan nyata.

Menurut Hamzah (2011) hakikat motivasi belajar adalah dorongan internal dan eksternal pada siswa-siswa yang sedang belajar untuk mengadakan 
perubahan tingkah laku, pada umumnya dengan beberapa indikator atau unsur yang mendukung.

Dimyati dan Mudjiono (2009) ada tiga komponen utama dalam motivasi yaitu kebutuhan, dorongan dan tujuan. Kebutuhan terjadi apabila individu merasa tidak ada keseimbangan antara apa yang ia miliki dengan apa yang ia harapkan. Dorongan merupakan kekuatan mental untuk melakukan kegiatan dalam rangka memenuhi harapan sedangkan tujuan merupakan hal yang ingin dicapai oleh seorang individu.

\section{Stres}

Hawari (2003) berpendapat bahwa istilah stres tidak dapat dipisahkan dari distress dan depresi, karena satu sama lainnya saling terkait. Stres merupakan reaksi fisik terhadap permasalahan kehidupan yang dialaminya dan apabila fungsi organ tubuh sampai terganggu dinamakan distress. Sedangkan depresi merupakan reaksi kejiwaan terhadap stressor yang dialaminya. Dalam banyak hal manusia akan cukup cepat untuk pulih kembali dari pengaruh-pengaruh pengalaman stres. Manusia mempunyai suplai yang baik dan energi penyesuaian diri untuk dipakai dan diisi kembali bilamana perlu.

Dougall \& Baum (2001); Hobfoll (dalam Sarafino, 2006) mengemukakan tiga pendekatan untuk menentukan definisi stres, yaitu: a. Pendekatan yang berfokus pada lingkungan, stres dilihat sebagai stimulus yaitu kondisi ketika suatu pekerjaan menuntut kemampuan tertentu dari seseorang atau pengalaman yang menyedihkan seperti kehilangan salah satu anggota keluarga; b. Pendekatan berfokus pada reaksi individu, stres dilihat sebagai sebuah respon. Respon bisa berupa respon psikologis seperti pola-pola pemikiran, emosi seperti kecemasan dan respon fisik seperti meningkatnya detak jantung; c.
Pendekatan berfokus pada individu dan lingkungan, stres dilihat tidak hanya sebagai stimulus dan respon tetap lebih sebagai proses.

Menurut Richard (2010) stres adalah suatu proses yang menilai suatu peristiwa sebagai sesuatu yang mengancam, ataupun membahayakan dan individu merespon peristiwa itu pada level fisiologis, emosional, kognitif dan perilaku.

Abuddin (2016) Berlaku ihsan (baik) kepada segala sesuatu. Dari Syaddad bin Aus berkata, "Ada dua hal yang aku hafal dari Rasulullah Shallallahu 'alaihi wasallam, beliau berkata, 'Sesungguhnya Allah mewajibkan berlaku ihsan kepada segala sesuatu. Bila kalian membunuh (seperti binatang berbahaya), bunuhlah dengan cara yang baik. Bila kalian menyembelih binatang, sembelihlah dengan cara yang baik. Hendaknya seorang dari kalian mengasah pisaunya dan memberi kemudahan kepada sembelihannya”. (HR Muslim)

\section{Lingkungan Islami}

Abuddin (2016) merusak lingkungan merupakan salah satu sifat orang munafik.

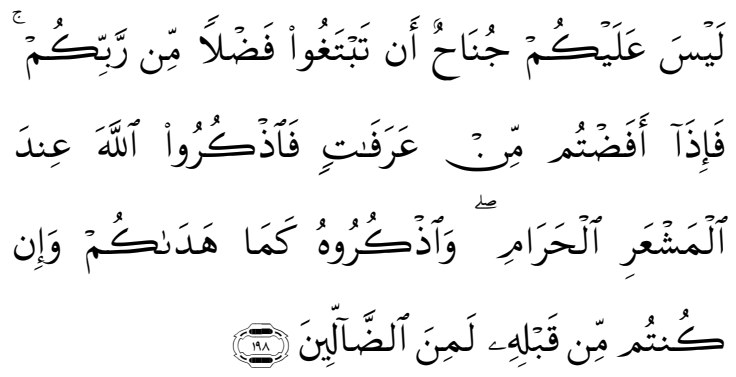

Artinya: "Dan apabila ia berpaling (dari kamu), ia berjalan di bumi untuk mengadakan kerusakan padanya, dan merusak tanam-tanaman dan binatang ternak, dan Allah tidak menyukai kebinasaan." (QS Al Baqarah: 205)

M. Ali Usman (2001) Larangan mencemari lingkungan. Dari Abu Hurairah Radhiyallahu 'anhu bahwa Nabi 
Muhammad Shallallahu 'alaihi wasallam bersabda: "Jauhilah dua perbuatan yang mendatangkan laknat!" Sahabat-sahabat bertanya, "Apakah dua perbuatan yang mendatangkan laknat itu?" Nabi menjawab, "Orang yang buang air besar di jalan umum atau di tempat berteduh manusia." (HR Muslim)

Dari Abu Hurairah Radhiyallahu 'anhu bahwa Nabi Muhammad Shallallahu 'alaihi wasallam bersabda: "Janganlah seorang dari kalian kencing di air tenang yang tidak mengalir kemudian mandi di dalamnya." (HR Bukhari dan Muslim)

Dari Abu Hurairah radhiyallahu anhu berkata: Rasulullah عل يه الله صدلى bersabda artinya :"Setiap anak dilahirkan atas dasar fitrah, maka sesungguhnya kedua orang tuanya lah yang menjadikan dia Majusi, Yahudi, dan Nasrani." Hadist tersebut menjelaskan bahwa orang tua lah yang memegang peranan penting dalam membentuk kepribadian anak didik. Anak yang dilahirkan dalam keadaan suci adalah menjadi tanggung jawab orang tua untuk mendidiknya.

Dalam hal ini Allah berfirman dalam Q. S. At-Tahrim ayat 6 yang artinya :" Hai orang-orang yang beriman, peliharalah dirimu dan keluargamu dari api neraka yang bahan bakarnya adalah manusia dan batu; penjaganya malaikatmalaikat yang kasar, keras, dan tidak mendurhakai Allah terhadap apa yang diperintahkan-Nya kepada mereka dan selalu mengerjakan apa yang diperintahkan". Disitulah letak tanggung jawab orang tua untuk mendidik anakanaknya karena anak adalah amanah dari Allah SWT yang diberikan kepada orang tua yang kelak akan dipertanggung jawabkan atas pendidikan anak-anaknya. Unsur utama yang menjadi landasan pokok dalam pendidikan lingkungan keluarga yaitu adanya rasa kasih sayang serta terselenggaranya kehidupan beragama yang mewarnai kehidupan pribadi atau keluarga. Baik dan buruknya kepribadian seorang anak akan sangat bergantung pada baik buruknya pelaksanaan pendidikan Islam di keluarga. Dalam hal ini, orang tua sebagai pendidik dan anak sebagai peserta didik. Orang tua dituntut menjadi teladan bagi anakanaknya, baik berkenaan dengan ibadah, akhlak, dan lain sebagainya. Oleh sebab itu, keluarga hendaknya dapat menciptakan suasana yang edukatif sehingga anak didiknya tumbuh dan berkembang menjadi manusia sebagaimana yang menjadi tujuan ideal dalam pendidikan Islam. Dengan begitu, kepribadian anak yang Islami akan terbentuk sejak dini sehingga menjadi modal awal dalam menentukan proses pendidikan yang akan ia jalani.

Lingkungan ialah ruang dan waktu yang menjadi tempat eksistensi manusia. Sedangkan Islam merupakan agama yang diturunkan kepada nabi Muhammad SAW sebagai nabi dan Rasul terakhir untuk menjadi pedoman hidup seluruh manusia hingga akhir zaman. Jadi lingkungan Islami yakni suatu lingkungan yang didalamnya terdapat ciri-ciri keislaman yang memungkinkan terselenggaranya pendidikan Islam dengan baik.

Fungsi lingkungan Islami yakni menunjang terjadinya proses kegiatan belajar mengajar secara aman, tertib dan berkelanjutan. Alquran memberi isyarat tentang pentingnya menciptakan suasana saling tolong menolong dan saling mensehati (motivasi) agar kegiatan yang dijalankan manusia dapat berjalan baik. Dahulu, sebelum belajar di madrasahmadrasah, kaum muslimin belajar di kutab yang disana diajarkan bagaimana cara membaca dan menulis huruf Alquran, dan kemudian diajarkan ilmu agama dan ilmu Alquran. Dari uraian tersebut dapat di identifikasikan bahwa lingkungan atau tempat berlangsungnya kegiatan 
pendidikan Islam terdiri dari rumah, masjid, kutab dan madrasah. Pada perkembangan selanjutnya institusi lembaga pendidikan itu disederhanakan menjadi lingkungan sekolah, perguruan tinggi (formal) dan lingkungan luar sekolah (informal). Lingkungan luar sekolah (informal) terdiri dari lingkungan keluarga dan lingkungan masyarakat. Seseorang memperoleh informasi, pengetahuan latihan dan bimbingan sesuai dengan usia dan kebutuhan, dengan tujuan mengembangkan tingkatan keterampilan, sikap, dan nilai-nilai yang memungkinkan baginya bertindak efisien dan efektif dalam lingkungan keluarga dan masyarakat. Sehingga dengan lingkungan islami akan jauh dari stress dan selalu ada motivasi untuk selalu meningkatkan prestasi belajar.

\section{METODE PENELITIAN}

Penelitian ini merupakan penelitian eksperimen. Eksperimen dilakukan pada, mahasiswa Prodi Manajemen Universitas Djuanda Bogor yang berjumlah 296 dengan perincian semester satu diambil 1 kelas berjumlah 56 , semester tiga diambil 1 kelas berjumlah 59 mahasiswa dan semester tujuh diambil 2 kelas berjumlah 181 mahasiswa. Dengan demikian, penelitian ini dikategorikan sebagai eksperimen semu (quasi eksperimen).

Rencana penelitian ini mengikuti desain penelitian eksperimen post-test only control sedangkan Populasi dalam penelitian ini adalah Prodi Manajemen Universitas Djuanda Bogor di tiga Jenjang semester yaitu semester 1 kita ambil 1 kelas, semester 3 kita ambil 1 kelas dan semester 7 kita ambil 2 kelas yaitu kelas regular dan kelas karyawan. Sedangkan jumlah sampel dalam penelitian ini sebanyak 296 responden. Teknik pengambilan sampel yang saya digunakan adalah sampel jenuh, yaitu teknik penentuan sampel dengan mengambil semua populasi ada. Skala pengukuran menggunakan skala likert, dan instrumen yang digunakan adalah kuesioner dan wawancara. Penelitian ini menggunakan teknik analisis kualitatif dan kuantitatif. Analisis kuantitatif menggunakan program SPSS, dengan menguji validitas dan uji reliabilitas, kemudian uji koefisien korelasi, uji regresi linear sederhana untuk mengetahui pengaruh dan arah dari masing-masing variabel independen (X) terhadap variabel dependen (Y) dan variable moderator (Z), setelah itu menguji koefisien determinasi, dan uji t dilakukan untuk melihat seberapa jauh pengaruh satu variabel independen secara individual dalam menerangkan variabel dependennya, selanjutnya regresi linear berganda untuk mengetahui bagaimana keadaan variabel dependen $(\mathrm{Y})$.

\section{Menurut Sugiyono}

"variabel intervening adalah variabel yang secara teoritis mempengaruhi hubungan antara variabel independen dengan dependen, tetapi tidak dapat diamati dan diukur. Variabel ini merupakan variabel penyela/antara yang terletak di antara variabel independen dan dependen, sehingga variabel independen tidak langsung mempengaruhi berubahnya atau timbulnya variabel dependen." Apabila dua atau lebih variabel independennya (X) di naik-turunkan, serta uji sobel yang merupakan uji untuk mengetahui apakah hubungan yang melalui sebuah variabel mediasi secara signifikan mampu sebagai mediator dalam hubungan tersebut. Maka peneliti mencoba menggunakan Uji sobel untuk mengetahui seberapa jauh mediasi variabel campur tangan (Z) secara bersama-sama dapat mempengaruhi variabel dependennya (Y). Dimana Sobel test mengunakan uji $\mathrm{z}$ dengan rumus sebagai berikut :

$$
z=\frac{a b}{\sqrt[a]{\left(b^{2} S E_{a}^{2}\right)+\left(a^{2} S E_{b}^{2}\right)}}
$$


Dimana :
$\mathrm{a}=$ Koefisien regresi variabel independen terhadap variabel mediasi.

$\mathrm{b}=$ Koefisien regresi variabel mediasi terhadap variable dependen.

$\mathrm{SE}=$ Standart error of estimation dari pengaruh variabel independen terhadap variabel mediasi.

$\mathrm{SE}=$ Standart error of estimation dari pengaruh variabel mediasi terhadap variabel dependen.

\section{HASIL DAN PEMBAHASAN}

Peneliti untuk mendapatkan hasil penelitian ini menggunakan beberapa analisis data diantaranya : uji koefisien korelasi, uji regresi linear sederhana, koefisien determinasi, uji regresi linear berganda dan uji signifikansi. Berdasarkan hasil pengujian yang telah dilakukan di Mahasiswa Prodi Manajemen Universitas Djuanda Bogor, maka diperoleh hasil sebagai berikut :

\section{Tabel 1. Hasil Penelitian}

\begin{tabular}{llcccc}
\hline \multirow{2}{*}{ No. } & \multicolumn{1}{c}{ Uji Hipotesis } & \multirow{2}{*}{ Uji } & \multicolumn{2}{c}{ Hasil Uji } & Keterangan \\
& & Korelasi & Detreminasi & t/F Hitung & Hipotesis \\
\hline 1 & Motivasi terhadap prestasi belajar & 0,687 & $46,5 \%$ & 8,984 & Ha diterima \\
\hline 2. & Motivasi terhadap lingkungan Islami & 0,517 & $27,44 \%$ & 5,836 & Ha diterima \\
\hline 3. & Stres terhadap prestasi belajar & 0,752 & $56,74 \%$ & 3,574 & Ha diterima \\
\hline $\begin{array}{l}\text { Sres terhadap lingkungan belajar } \\
\text { Islami }\end{array}$ & 0,632 & $39,21 \%$ & 7,683 & Ha diterima \\
\hline & $\begin{array}{l}\text { Lingkungan belajar Islami sebagai } \\
\text { variabel Konvariabel terhadap } \\
\text { prestasi belajar. }\end{array}$ & & & \\
& $\begin{array}{l}\text { Motivasi terhadap prestasi belajar } \\
\text { melalui lingkungan Islami }\end{array}$ & 0,629 & $39,23 \%$ & 3,607 & Ha diterima \\
\hline & $\begin{array}{l}\text { Stres terhadap prestasi belajar melalui } \\
\text { lingkungan belajar Islami }\end{array}$ & 0,408 & $16,66 \%$ & 4,281 & Ha diterima \\
\hline
\end{tabular}

\section{Sumber : Data Olahan (2020)}

Berdasarkan Tabel 1. dapat diketahui bahwa hasil uji t (uji signifikansi parsial) dan uji sobel (uji signifikansi simultan atau bersama-sama) menunjukkan bahwa :

1. Motivasi memiliki pengaruh terhadap prestasi belajar dimana nilai t hitung $(8,984)>\mathrm{t}$ tabel $(1,986)$ sehingga hipotesis diterima.

2. Motivasi memiliki pengaruh terhadap lingkungan belajar Islami, dimana nilai $\mathrm{t}$ hitung $(5,836)>\mathrm{t}$ tabel $(1,986)$ sehingga hipotesis diterima.

3. Stres memiliki pengaruh terhadap prestasi belajar dimana nilai t hitung $(3,574)>\mathrm{t}$ tabel $(1,986)$ sehingga hipotesis diterima.

4. Stres memiliki pengaruh terhadap lingkungan belajar Islami dimana nilai t hitung $(7,683)>t$ tabel $(1,986)$

5. Lingkungan belajar Islami memiliki pengaruh terhadap prestasi belajar dimana nilai $\mathrm{t}$ hitung $(3,607)>\mathrm{t}$ tabel $(1,986)$ sehingga hipotesis diterima.

6. Motivasi memiliki pengaruh terhadap prestasi belajar melalui lingkungan belajar Islami dimana nilai $\mathrm{t}$ hitung $(4,281)>t$ tabel $(1,986)$ sehingga hipotesis diterima. 
7. Stres memiliki pengaruh terhadap prestasi belajar melalui lingkungan belajar Islami dimana nilai $\mathrm{t}$ hitung $(2,942)>\mathrm{t}$ tabel $(1,986)$ sehingga hipotesis diterima.

Tabel 2. Hasil Uji Regresi Motivasi Terhadap Prestasi Belajar Coefficients $^{\mathrm{a}}$

\begin{tabular}{|c|c|c|c|c|c|c|}
\hline \multirow{3}{*}{\multicolumn{2}{|c|}{ Model }} & \multicolumn{5}{|c|}{ Standardized } \\
\hline & & \multicolumn{2}{|c|}{ Unstandardized Coefficients } & \multirow{2}{*}{$\frac{\text { Coefficients }}{\text { Beta }}$} & \multirow[b]{2}{*}{$\mathrm{T}$} & \multirow[b]{2}{*}{ Sig. } \\
\hline & & $\mathrm{B}$ & Std. Error & & & \\
\hline \multirow[t]{2}{*}{1} & (Constant) & 4.813 & 1.657 & & 2.903 & .006 \\
\hline & Total X1 & .884 & .115 & .627 & 7.676 & .000 \\
\hline
\end{tabular}

a. Dependent Variable: totally

Sumber : Data Olahan (2020)

Berdasarkan Tabel 2. dapat hubungan yang positif dengan prestasi diketahui bahwa nilai koefisien regresi belajar, dimana dapat dikatakan semakin untuk variabel motivasi bernilai positif baik motivasi, maka semakin baik tingkat sebesar 0,884. Hal ini menunjukkan prestasi belajar. bahwa variabel motivasi memiliki

Tabel 3. Hasil Uji Regresi Motivasi Terhadap Lingkungan Belajar Islami Coefficients ${ }^{\mathrm{a}}$

\begin{tabular}{|c|c|c|c|c|c|}
\hline \multirow[b]{3}{*}{ Model } & \multicolumn{5}{|c|}{ Standardized } \\
\hline & \multicolumn{2}{|c|}{ Unstandardized Coefficients } & \multirow{2}{*}{$\frac{\text { Coefficients }}{\text { Beta }}$} & \multirow[b]{2}{*}{$\mathrm{T}$} & \multirow[b]{2}{*}{ Sig. } \\
\hline & B & Std. Error & & & \\
\hline 1 (Constant) & 6.697 & 1.384 & & 4.849 & .000 \\
\hline Total X1 & .452 & .077 & .519 & 5.832 & .000 \\
\hline
\end{tabular}

a. Dependent Variable: totalz

Sumber : Data Olahan (2020)

Berdasarkan Tabel 3. dapat hubungan yang positif dengan lingkungan diketahui bahwa nilai koefisien regresi belajar Islami, dimana dapat dikatakan untuk variabel motivasi bernilai positif semakin baik motivasi, maka semakin sebesar 0,452. Hal ini menunjukkan tinggi tingkat lingkungan belajar Islami. bahwa variabel motivasi memiliki

Tabel 4. Hasil Uji Regresi Stres Terhadap Prestasi Belajar Coefficients $^{\mathrm{a}}$

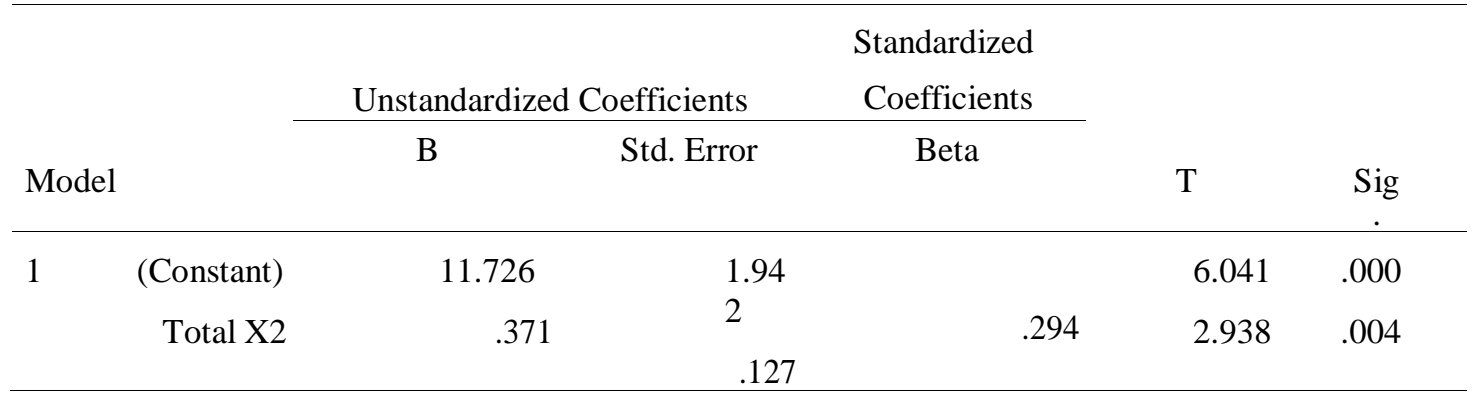

a. Dependent Variable: totally

Sumber : Data Olahan (2020) 
Berdasarkan Tabel 4. dapat diketahui bahwa nilai koefisien regresi untuk variabel stres bernilai positif sebesar 0,371. Hal ini menunjukkan bahwa variabel stres memiliki hubungan yang positif dengan prestasi belajar, dimana dapat dikatakan semakin baik stres, maka semakin baik tingkat prestasi belajar.

Tabel 5. Hasil Uji Regresi Stres Tehadap Lingkungan Belajar Islami Coefficients $^{\mathrm{a}}$

\begin{tabular}{|c|c|c|c|c|c|c|}
\hline \multirow{3}{*}{\multicolumn{2}{|c|}{ Model }} & \multicolumn{5}{|c|}{ Standardized } \\
\hline & & \multicolumn{2}{|c|}{ Unstandardized Coefficients } & \multirow{2}{*}{$\begin{array}{c}\text { Coefficients } \\
\text { Beta }\end{array}$} & \multirow[b]{2}{*}{$\mathrm{T}$} & \multirow[b]{2}{*}{$\mathrm{Sig}$} \\
\hline & & B & Std. Error & & & \\
\hline \multirow[t]{2}{*}{1} & (Constant) & 8.936 & 1.352 & & 6.595 & .000 \\
\hline & Total X2 & .377 & .086 & .407 & 4.283 & .000 \\
\hline
\end{tabular}

Sumber : Data Olahan (2020)

Berdasarkan Tabel 5. dapat hubungan yang positif dengan diketahui bahwa nilai koefisien regresi lingkungan belajar Islami, dimana dapat untuk variabel stres bernilai positif dikatakan semakin baik stress, maka sebesar 0,377. Hal ini menunjukkan semakin tinggi tingkat lingkungan bahwa variabel stress memiliki belajar Islami.

Tabel 6. Hasil Uji Regresi Lingkungan Belajar Islami Terhadap Prestasi Belajar Coefficients $^{\mathrm{a}}$

\begin{tabular}{|c|c|c|c|c|c|c|}
\hline \multirow[b]{3}{*}{ Model } & & \multicolumn{5}{|c|}{ Standardized } \\
\hline & & \multicolumn{2}{|c|}{ Unstandardized Coefficients } & Coefficients & \multirow[b]{2}{*}{$\mathrm{T}$} & \multirow[b]{2}{*}{ Sig. } \\
\hline & & B & Std. Error & Beta & & \\
\hline \multirow[t]{3}{*}{1} & (Constant) & 3.0 & 1.614 & & 1.887 & 063 \\
\hline & Total Z & 45 & .091 & .683 & 8.990 & .000 \\
\hline & & .815 & & & & \\
\hline
\end{tabular}

a. Dependent Variable: totally

Sumber : Data Olahan (2020)

Berdasarkan Tabel 6. dapat diketahui bahwa nilai koefisien regresi untuk variabel lingkungan belajar Islami bernilai positif sebesar 0,815 . Hal ini menunjukkan bahwa variabel lingkungan belajar Islami memiliki hubungan yang positif dengan prestasi belajar, dimana dapat dikatakan semakin tinggi lingkungan belajar islami, maka semakin baik tingkat prestasi belajar.

Dari hasil perhitungan di atas, dapat ditarik kesimpulan bahwa penyebab mengapa pengaruh motivasi pada prestasi belajar secara langsung lebih besar dari pada pengaruh stres pada prestasi belajar melalui lingkungan belajar Islami. Hal tersebut dikarenakan faktor pengendalian diri dan pengaturan diri yang termasuk dalam kategori motivasi secara praktis bisa langsung digunakan untuk mendukung prestasi belajar.

\section{KESIMPULAN}

Motivasi dan stres memiliki pengaruh secara parsial terhadap prestasi belajar. Hasil tersebut mengindikasikan bahwa motivasi akan memberikan peran yang lebih besar dari 
pada stres untuk meningkatkan prestasi belajar mahasiswa manajemen Fakultas Ekonomi Universitas Djuanda Bogor. Lingkungan belajar Islami memiliki pengaruh secara parsial terhadap prestasi belajar. Hasil ini mengindikasikan bahwa dengan lingkungan belajar Islami yang dimiliki para mahasiswa manajemen Fakultas Ekonomi Universitas Djuanda Bogor akan menghasilkan prestasi belajar yang baik. Motivasi dan Stres akademik mempengaruhi secara bersama-sama terhadap lingkungan belajar Islami mahasiswa manajemen Fakultas Ekonomi Universitas Djuanda Bogor.

\section{DAFTAR PUSTAKA}

A.M, Sardiman. 2010. Interaksi dan Motivasi Belajar Mengajar. Rajawali Pers. Jakarta.

Abuddin, Nata. 2013. Filsafat Pendidikan Islam. Gaya Media Pratama. Jakarta.

Abuddin, Nata. 2016. Ilmu Pendidikan Islam. Predanamedia Group. Jakarta.

Dalyono. 2009. Interaksi dan Motivasi Belajar Mengajar. Raja Grafindo. Jakarta.

Newstrom. J. \& Davis, K. 2007. Perilaku dalam Organisasi. Erlangga. Jakarta.

Dimyati dan Mudjiono .2009. Belajar dan Pembelajaran. PT Reneka Cipta. Jakarta.

Dougall, A. L., dan Baum, A. 2001. Stress, Health, and Illness. In A. Baum, T. A. Revension, dan J. E. Singer. Handbook of health psychology. Erlbaum. New Jersey.

Hamalik, Oemar. 2014.Proses Belajar Mengajar. PT Bumi Aksara. Jakarta.
Hamzah, B. Uno. 2011. Teori Motivasi dan Pengukurannya. Bumi Aksara. Jakarta.

Hawari, D. 2003. Manajemen Stres, Cemas dan Depresi. FKUI. Jakarta.

M. Ali Usman, Dalan. 2001. Hadis Qudsi. CV Diponegoro. Bandung.

Richard. 2010. Coping with Stress In a Changing World. McGrawHill. New York.

Widoyoko, S. Eko Putro. 2012. Evaluasi Program Pembelajaran. Pustaka Belajar. Yogyakarta.

Sakamoto, Reiko \& Minoura, Kazuya \& Usui, Akira \& Ishizuka, Yoshikazu \& Kanba, Shigenobu. 2005. Effectiveness of Aroma on Work Efficiency: Lavender Aroma during Recesses Prevents Deterioration of Work Performance. Chemical senses. 30. 683-91.

Sarafino, E.P. 2006. Health Psychology : Biopsychosocial Interactions. Fifth Edition. John Wiley \& Sons. USA.

Sugiyono. 2012. Memahami Penelitian Kuantitatif. Alfabeta. Bandung. 